\title{
THE CONSTRUCTION AND EVALUATION OF A SCALE OF CONSUMER SHOPPING EXPERIENCE
}

\author{
BA GILLHAM \\ F CROUS \\ JM SCHEPERS \\ Programme in Industrial Psychology \\ Department of Human Resource Management \\ Rand Afrikaans University
}

\begin{abstract}
Generally speaking consumer psychology have focused primarily on the problem solving and decision making processes underlying buying behaviour. As a result, the experience of consumers engaging in the activity of shopping has been neglected. The purpose of this study was to construct and evaluate a scale of consumer shopping experience. The instrument indicated that shopping experience is not merely a means to an end, but in many cases an end in itself. The Shopping Experience Survey consisting of 54 items was developed and administered to 426 respondents consisting of students at a large tertiary institution. The study indicated that the Shopping Experience Survey is highly reliable $\left(\mathrm{r}_{\mathrm{xx}}=0,965\right)$ and sensitive to group differences.
\end{abstract}

\section{OPSOMMING}

Benaderings tot verbruikersielkunde fokus in die algemeen hoofsaaklik op die probleemoplossings- en besluitnemingsprosesse onderliggend aan aankoopgedrag. Gevolglik het die ervarings wat verbruikers tydens die aankoopproses beleef, nie veel aandag geniet nie. Die doel van die onderhawige studie was om 'n skaal van verbruikeraankoopbelewenisse te konstrueer en te evalueer. Die instrument het aangedui dat die aankoopbelewenis nie ' $n$ middel tot ' $n$ doel is nie, maar ' $n$ doel insigself is. Die Shopping Experience Survey, bestaande uit 54 items, is ontwikkel en geadministreer aan 426 respondente van 'n groot residensiële tersiêre instelling. Met die studie is bevind dat die Shopping Experience Survey hoogs betroubaar is $\left(r_{x x}=0,965\right)$ en sensitief is vir groepverskille.

The role and importance of the shopping experience within consumer psychology has been recognised for a long time. According to Abbott (1955),

The thesis may be stated quite simply. What people really desire are not products but satisfying experiences. Experiences are attained through activities. In order that activities may be carried out, physical objects or the services of human beings are usually needed ( $p 7)$.

Although the role of the shopping experience was identified early, limited research has focused on a deeper understanding of its nature and role within the field of consumer psychology. Confronted with any number of subjective reasons for engaging in shopping experiences, researchers have focused much of their attention on the more clearly understandable and more empirically objective method of linking consumer behaviour to functional or efficacious properties of a product or brand. Consequently, a limited understanding of consumer shopping experiences has been developed and, aside from cursory mention, only piecemeal attempts made to describe it. Therefore, this study aims to construct a scale of consumer shopping experiences and highlight its application within the discipline of consumer psychology.

Within traditional models of consumer behaviour an understanding of the shopping experience is limited to purchasing decisions. These traditional models have primarily been generated and expanded by the discipline of marketing. As a result, the understanding of consumer behaviour and motivation has been sought only in as far as this facilitates the ongoing purchase of a product or brand (Foxall, Goldsmith, \& Brown, 1998). In other words, the consumer is relegated to being understood very linearly on the basis of explaining and maximising consumption. The marketing approach holds that the actual engagement in the shopping experience is a cognitive process merely serving as a means to an end.

Within the changing landscape of the consumer, this view fails to adequately capture the shopping experience as a significant

Requests for copies should be addressed to: F Crous, Department of Human Resource Management, RauUniversity, PO Box 524, Auckland Park, 2006 motivator within consumer behaviour paradigms. Because many consumers actively choose to engage in the shopping experience, the experience moves from being an unavoidable means to an end, to an end in itself. In addition, this active choice to engage in the shopping experience may even play a factor in determining product consumption.

Figure 1 summarises the research problem addressed in this paper. In addition to summarising the research problem, figure 1 recognises the role of the cognitive approach to consumer behaviour, but gives equal consideration to the shopping experience and it's outcomes within the consumption process.

In Figure 1, intrinsic and extrinsic factors create a predisposition to consumer behaviour within the individual that affects his or her consumption orientation. The individual then has to have a shopping experience irrespective of that orientation. The consumption orientation may be functional/cognitive or utilitarian (serving as a means to an end) or it may be symbolic/expressive or emotional (an end in itself) in nature. Traditional models of consumer behaviour then propose that from this stance the shopping experience culminates in the purchase of a product or brand. However, what happens if the individual does not logically follow the traditional approach and purchase a product? Is the consumer behaviour in this instance merely ignored and forgotten until such time as the consumer behaves appropriately? The postulation of this paper indicates that there may indeed be other outcomes derived from the shopping experience namely fun, leisure, value, play, aesthetic appreciation or a flow experience. These are some but not all of the potential outcomes that the individual might ascribe to a shopping experience. These potential outcomes are discussed further in the paper.

\section{Contrasting approaches to consumer behaviour}

Considerable research has focused on understanding human needs and motivations. Many of these theories and models have facilitated an understanding of human needs and motivation within the context of consumer behaviour. According to Bhat and Reddy (1998) there are two distinct schools of thought relating to consumer behaviour, being rational/cognitive and symbolic/expressive respectively. 


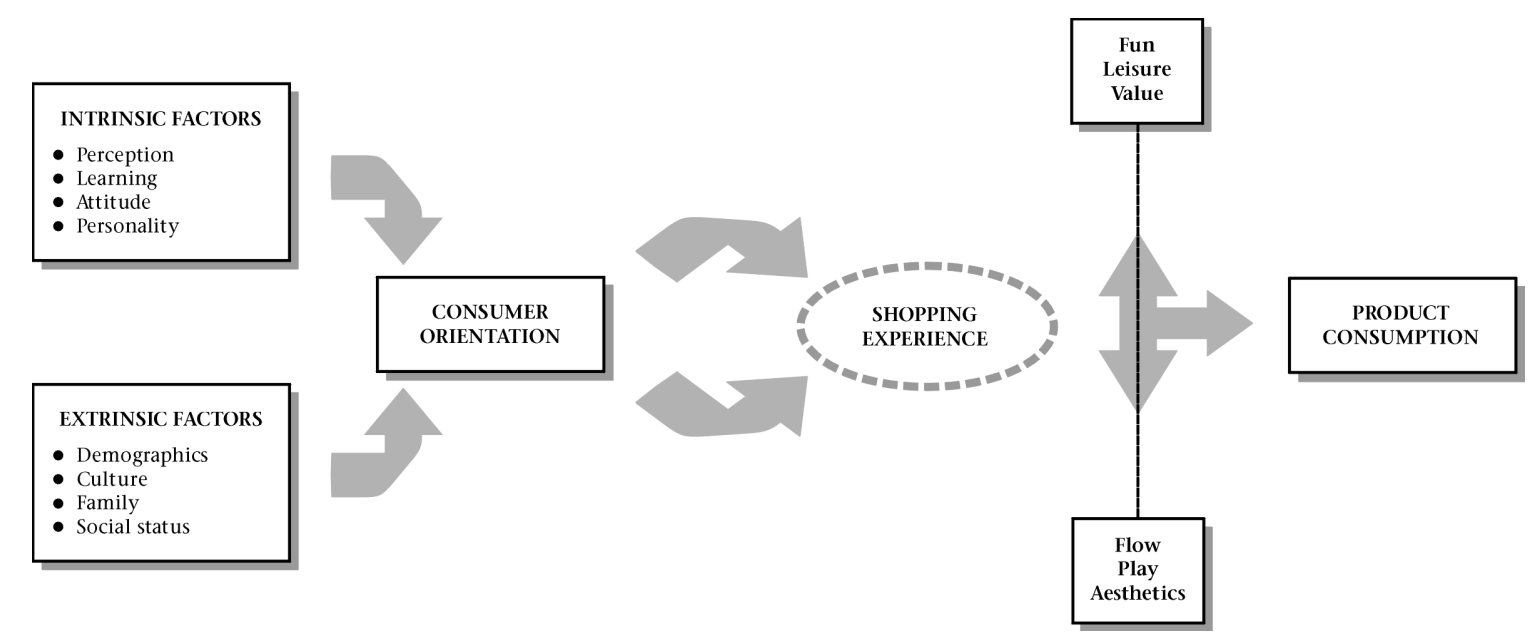

Figure 1: Possible outcomes of the shopping experience independent of product consumption

The rational or cognitive approach suggests that consumers are rational and their consumption behaviour is based on maximising utility (Bhat \& Reddy, 1998). In other words, products are bought on the basis of physical objective criteria such as price, product features, quality and functionality (Overton, 1981; Schiffman \& Kanuk, 1994). In arriving at an ultimate decision based on utility, the consumer goes through a variety of cognitive processes that focus on rational comparison and contrast of tangible aspects of the product. The outcome of this cognitive process is that a judgement rule is made which then becomes the basis for final decision-making (Bhat \& Reddy, 1998; East, 1997).

Although comprehensive in its application to cognitive consumer behaviour and decision-making, this approach inadequately captures the motivations of consumers who purchase and consume products that hold emotional value (Holbrook \& Hirschman, 1982). Holbrook and Hirschman (1982) point out that the aspects of multi-sensory imagery, fantasy, fun and emotions associated with product consumption is not explained within the framework of cognitive decision making. Consequently, Holbrook and Hirschman (1982) postulate a model that is more subjective and takes into account individual tastes and intangible experiences associated with consumer behaviour. This approach considers individual, personal and subjective criteria such as taste, pride, adventure and expression within consumer motivation (Holbrook \& Hirschman, 1982; Schiffman \& Kanuk, 1994).

Bhat and Reddy (1998) summarise these two schools of thought, which seek to classify consumer orientation, as being driven either by functional/cognitive/utilitarian motivation or symbolic/expressive/emotional motivation. Park, Jaworski and MacInnis (1986) view the two schools as dichotomous by classifying consumer motivation and needs orientation as being either functional or symbolic in nature. Functional needs pertain to specific and practical consumption (biological needs), whereas symbolic needs relate to self image and social identification (affiliation needs).

By default then, intrinsic psychological factors affecting consumer behaviour (perception, learning, attitude, and personality) as well as extrinsic factors (culture, family, social status, demographic factors) are also seen within the ambit of the two dominant schools of thought pertaining to consumer motivation and behaviour. Intrinsic and extrinsic factors are thus seen as determinants in functional and symbolic orientations to consumer behaviour, which translates itself into a specific product purchasing decision. Having recognised the dominant schools of thought related to consumer behaviour, it is important to understand in more detail the role of motivation and behaviour. This relationship is explored in the next section of the paper.
Shopping experience and motivation

A critical aspect of experience is that it is different from person to person but undoubtedly comes from an intrinsic source. In order to experience shopping in an intrinsically meaningful way, an aspect of motivation is necessary. Reversal theory (Apter, 1982) supports the intrinsic experience of motivation within the shopping experience. Reversal theory holds that a piece of behaviour does not necessarily have a meaning beyond its personal value to an individual. Apter (1982) draws the comparison between mental states concerned with behaviour and how these are expressed. In other words, a specific piece of behaviour may have multiple mental states associated with it. Equally, one mental state may express itself in multiple behaviours.

The application of this logic provides an insight into the importance of experience within consumer behaviour disciplines. Motivation, according to Apter (1982), is inconsistent but always intrinsic in nature. In terms of shopping, reversal theory stresses that an activity that is biologically gratuitous, doesn't necessarily mean it has no psychological point. Psychological satisfactions are sometimes unrelated to biological necessities such as product consumption.

Traditional views of consumer behaviour adopt a homeostatic approach to purchasing and buying motivation. In other words, if there is tension, the organism will seek out a product until the tension is satisfied and balance or stability is restored. The act of purchasing then becomes the means to the end, divorced of the experience derived in restoring balance. The nature of the motivation in this case is external, being closely linked to specific aspects of the product and its features. This link leads the consumer to express consumption in a certain way.

In contrast, within psychological reversals (behaviour) there are states of mind which help to explain reversals when they happen. The "frames of mind" which determine certain phenomenological characteristics of motivation at a given time are known as meta-motivational states (Apter, 1982). Simply stated, these states explain the way the individual interprets his own motives. These mental states are defined in terms of the way in which the subject interprets aspects of his/her subjective experience. Mental states manifest themselves primarily as either telic or paratelic in nature.

Motivation as Telic and Paratelic States

Telic and paratelic meta-motivational states provide compelling support for the recognition of the shopping experience as critical in consumer behaviour.

According to Apter (1982) the telic state is defined as a phenomenological state in which the individual is primarily orientated towards, or feels the need to be primarily orientated towards some essential goal or goals (traditional consumer 
behaviour approach). In contrast, the paratelic state is defined as a state in which the individual is primarily orientated towards or feels the need to be primarily orientated towards some aspect of his/her continuing behaviour and its related sensations (Apter, 1982).

If the consumer is orientated towards an essential goal or goals at any given time, he/she may be said to be in a telic state and the resulting behaviour directed towards these goals would be seen as telic behaviour. Paratelic behaviour in contrast is expressed where goals are not seen as essential (Apter, 1982). This captures the essence of the paper in that whilst consumer behaviour is sometimes purely about acquiring a specific product, this inadequately defines the consumer behaviour which may manifest itself in other consumption experiences. Traditional consumer behaviour practitioners have largely ignored the paratelic state where the activity is itself the goal.

TABLE 1

COMPARING TELIC AND PARATELIC MOTIVATIONS (FROM APTER, 1982; CSIKSZENTMIHALYI, 1990)

\begin{tabular}{cll}
\hline \multicolumn{1}{c}{ MOTIVATIONS } & \multicolumn{1}{c}{ TELIC } & \multicolumn{1}{c}{ PARATELIC } \\
\hline Means-Ends Motivation & $\begin{array}{l}\text { Essential goals } \\
\text { Imposed goals } \\
\text { Unavoidable goals }\end{array}$ & $\begin{array}{l}\text { Not essential goals } \\
\text { Freely chosen goals } \\
\text { Avoidable goals }\end{array}$ \\
& Reactive & Proactive \\
& Goal-oriented & Behaviour oriented \\
Time Motivations & Wish to complete & Wish to prolong \\
& Future-oriented & Present-oriented \\
& Planned & Spontaneous \\
& Pleasure of anticipation & Pleasure of sensation \\
& High rationality & Low rationality \\
preferred & preferred \\
Intensity Motivations & High arousal preferred
\end{tabular}

Apter (1982) contrasts the two states along three critical dimensions of motivation. The motivation dimensions include means-end, time and intensity. In the means-end dimension, the individual may pursue goals for essential (functional) or inessential (experiential, aesthetic) value. Time refers to either a here-and-now experience (telic) or a future-orientated (paratelic) state of mind. Intensity refers to the desired levels of rationality and arousal sought out by the individual. Table 1 summarises the relationships between the telic and paratelic states and the dimensions of motivation.

In considering Table 1 , it is clear that the cognitive decision making approach to consumer behaviour is found in the telic column. In contrast, the shopping experience itself, as an experience, more fully aligns itself with the characteristics in the paratelic column.

In summary, Apter (1982) asserts that reversal theory is concerned with the crucial factor of whether the situation is one in which the primary orientation is towards the achievement of an essential goal, whatever its source, or towards the enjoyment of the continuing activity.

\section{Flow and the shopping experience}

Very closely related to Apter's (1982) theory of telic and paratelic states is Csikszentmihalyi's (1990) notion of "flow" that lends support to the intrinsic power of experience within the individual. According to Csikszentmihalyi (1990), flow is described as a state of mind when consciousness is harmoniously ordered and there is a desire to pursue whatever the individual is doing, for its own sake. Flow is a theory of optimal experience, where the individual is so involved in an activity that the activity is worth engaging in for the sheer pleasure that it brings.
Csikszentmihalyi (1990) contrasts extrinsic motivation and intrinsic motivation primarily along the dimension of imposed goals and freely chosen goals. Imposed goals or freely chosen goals are realised through intent. In other words what the individual wants to get out of an experience. Intent, according to Csikszentmihalyi (1990) doesn't indicate why a person wants to do a certain thing, but simply states that he does.

Csikszentmihalyi (1990) points out that the key element of an optimal experience is that it is an end in itself. The pursuit of an activity, one that is done, not with the expectation of some future outcome, but simply because the doing itself is the reward, is known as an autotelic experience (Csikszentmihalyi 1990). The autotelic experience is analogous to Apter's (1982) paratelic metamotivational state. Csikszentmihalyi (1990) asserts that engaging in autotelic experiences, leads to the growth and development of the "autotelic self". The autotelic self is characterised by the setting of goals from an intrinsic source, becoming immersed in the activity, paying attention to what is happening (involvement) and learning to enjoy the immediate experience. Having understood the link between motivation and behaviour, the question is what outcomes do individuals potentially realise as a result of their engagement in shopping activities?

\section{Additional outcomes of the shopping experience}

Shopping activity that is independent of specific purchase needs or decisions has been given numerous labels. It may be referred to as recreational shopping (Ohanian \& Taschian, 1992; Bellenger \& Korgaonkar, 1980), consumer value (Holbrook, 1999), exploration (Stell \& Paden, 1999), leisure (Neulinger, 1974; Kelly, 1987), aesthetic shopping (Holbrook 1999) and play (Holbrook, 1999).

What these perspectives on the shopping experience have in common is that the consumer is not solely motivated to shop because of the need to solve a specific purchase problem (Stell \& Paden, 1999). Instead, the consumer engages in the shopping activity to increase stimulation and relieve boredom, satisfy their curiosity, learn about products, or to recreate and socialise with others. According to Stell and Paden (1999), although the shopping experience considers consumer activity not directly associated with a specific purchase, the outcomes of this behaviour have important marketing implications. Understanding some of the reasons why individuals engage in the shopping experience independently of purchasing, provides an insight into the importance of this aspect within consumer behaviour models.

\section{The shopping experience as consumer value}

According to Holbrook (1999) consumer value plays a crucial role in terms of marketing activities adopted. Holbrook (1999) defines consumer value as an interactive relativistic preference experience. In terms of shopping experience the two noteworthy elements of the definition are preference and experience. In the definition, Holbrook (1999) points out that consumer value is not a narrow concept limited to ultimate purchasing decisions exercised by the consumer. Instead, the nature of the subjective experience of the consumer is significant and shouldn't be ignored (Huber, Herrman \& Morgan, 2001). To this end Holbrook (1999) highlights the importance of the situational context of experience relating to the consumer. The situationspecific nature of decision making dictates that consumer behaviour is context-dependent and variable from one time frame or one location to another (Huber et.al., 2001).

Consumer value therefore resides not in the product purchased, not in the brand chosen, not in the object possessed but rather in the consumption experiences associated with them (Holbrook and Hirschman 1982; Woodruff and Gardial 1996). Having understood what is meant by the term consumer value, it is equally critical to understand the types of value in the consumer experience. According to Holbrook (1999) consumer value is either extrinsic or intrinsic in nature 
Extrinsic value pertains to a means-end relationship where consumption is focused on functional or utilitarian means of accomplishing some further purpose, aim, goal or objective (Bond, 1983). By contrast, intrinsic value manifests itself when the consumption experience is appreciated as en end in itself for its own sake - as self-justifying, ludic or autotelic (Bond, 1983; Csikszentmihalyi, 1990). Consumer value is explicit in its assertion that only an experience - and not some object - can be appreciated as an end in itself (Holbrook 1999). As a consequence then, the shopping experience in and of itself takes on a very different aspect in the key provision of intrinsic value within consumer motivation, irrespective of the extrinsic value of utility and functional expression, which may be derived from ultimate product purchase.

\section{Shopping as play}

Holbrook (1999) recognises that there is an often overlooked, yet critical link between extrinsic and intrinsic values. Efficiency, excellence, status and esteem represent the bias towards extrinsic (product) whilst play, aesthetics, ethics and spirituality are congruent with the intrinsic experience of shopping. Holbrook (1999) notes that play is a self-orientated experience actively sought after and engaged in for its own sake. In other words the nature of play is such that it is an experience pursued as an end in itself. As a self-orientated experience, actively sought and enjoyed for its own sake, play typically involves having fun.

Fun characterises the intrinsically motivated side of the familiar distinction made between work and leisure (Bond, 1983). According to Krubski (1997) more than one third of consumers are willing to be persuaded to make an unplanned purchase at point of sale - a tribute to the potential power of a pleasurable in-store experience. It is critically important to stress that play is not co-incidental within the consciousness of the consumer. It has a definite self-orientated focus, but more importantly is an active intention on the part of the consumer (Holbrook, 1999). Its self-orientated focus and its active intention link closely to what Csikszentmihalyi (1990) refers to as "mastery".

\section{Shopping as an aesthetic experience}

Whereas play is self-orientated, aesthetics refers to behaviour consumers engage in purely for its own sake - a self justifying or autotelic form of intrinsic value, irrespective of practical value (Holbrook 1999). In other words the consumer derives a sense of appreciation of some shopping experience valued intrinsically as a self-orientated end in itself (Hampshire, 1982). The hallmark of the aesthetic experience is that it is enjoyed purely for its own sake without regard to any further practical purpose that it might serve as a means to any other end. As a result the quality of an aesthetic shopping experience will be determined by the intensity and duration of an individual's concentration or focus on the experience (Csikszentmihalyi, 1990; Holbrook, 1999).

The context in which the aesthetic experience is embraced plays an important role. If the orientation to the shopping experience is practical or functional, the probability of the shopping experience being perceived as aesthetically fulfilling is minimised. It may happen that the actual product features themselves create aesthetic appreciation (colour, novelty or packaging). Conversely, if the shopping experience being engaged in is not a means to an end, the environment itself in which shopping occurs may be perceived as being aesthetic. An experience that is positively aesthetic will undoubtedly be engaged in on an ongoing basis. Consequently, aesthetically pleasant shopping experiences are likely to be repeated by the individual.

\section{Shopping as a leisure experience}

In his groundbreaking work on leisure, Neulinger (1974) recognised the importance of leisure within many spheres of the individual's life. Traditional views narrowly understood leisure in comparison to work (amount of leisure equivalent to proportion of time left over after work and maintenance commitments).
Neulinger (1974) deviates strongly from this view repositioning leisure as a subjective or "state of mind" definition. According to Neulinger (1974) two criteria must be met for an individual to experience leisure. These two criteria are perceived freedom and intrinsic motivation. Perceived freedom relates to whether the activity has been chosen freely without coercion, whereas intrinsic motivation refers to the internal properties of an experience rather than the consequences or outcomes thereof. Neulinger (1974) thus crystallises the notion that motivation is influenced by the experience directly associated with an activity and not only the outcomes realised. This idea closely supports Apter's (1982) concept of the meta-motivational state of mind.

According to Kelly (1987) leisure is more than an activity or an event, but rather involves a process. The mental states associated with leisure utilise information processing through sensory perception, forming an impression, which then receives attention. In addition, the mind processes the impression according to previously processed experiences. For most experiences however, the processing does not end there. The process continues into evaluation, in which the experience is categorised according to preformed attitudes of meaning. The consequence of this processing is that such an evaluation may also incorporate a disposition to take action in regard to the experience (Kelly, 1987). This clearly places the experience of leisure as an active process rather than a passive one. Leisure is something that the individual may actively seek out in the future as repeat behaviour on the basis of previously positive experiences.

The primary purpose of this study was the construction and evaluation of a shopping experience scale. It is important that in addition to high reliability a scale is robust enough to detect differences between groups. Since a range of potential experiences related to the shopping experience exists, a secondary aim of the research was to compare the experiences of groups with different biographical backgrounds in respect of age, gender, race and income. In considering those differences two hypotheses were generated. The first hypothesis is that there will be statistically significant differences between the shopping experiences of different race groups (Asian, Black, Coloured, White). The rationale for this hypothesis rests on the basis that fundamental shopping experiences are shaped through diverse historical and economic realities. In addition, a second hypothesis is that there are statistically significant difference between the means of males and females in respect of shopping experiences. The rationale for this hypothesis rests on the gender bias that tends to associate females more readily with shopping and its associated experiences.

\section{METHOD}

\section{Sample}

A sample of convenience representative of undergraduate industrial psychology students studying at a large tertiary institution was selected. A sample of 426 students participated in the study. The sample consisted of 308 females and 118 males. Of the sample, $65,6 \%$ were White, $16,5 \%$ were Black, $11,5 \%$ were Asian and 6,4\% were Coloured. The sample targeted the 18-24 age group as this group, commonly referred to as generation "X'ers," are the most demanding in terms of pursuing experiences within their life space (Schiffman \& Kanuk, 1994).

\section{Measuring instrument}

The Shopping Experience Survey (SES) is based on the research done by Csikszentmihalyi $(1975,1988,1990,1993)$ in the measurement of flow. The questionnaire consists of 54 items. The scale is designed to measure shopping experience analogous to the autotelic experience, which forms the basis of the flow experience. Apter's (1982) work on meta-motivational telic and paratelic states was integrated into the survey. The SES was constructed by drawing on the theoretical components in the 
domains of flow and motivation as well as the sub-domains linked to these. The sub-domains covered the areas of fun, play, leisure, aesthetics and consumer value that have been discussed in the theoretical component of the study. The final selection of items was done after a full item analysis. Each of the items in the SES is presented in the form of a seven-point scale. This format is most appropriate as it allows for a wide range of responses ranging from hardly ever having a positive experience whilst shopping to having such experiences quite often. In addition it is possible with this scale to more accurately gauge the intensity of the experience. The survey was constructed in English. In its complete form, the SES consists of three sections: an instruction section, a biographical information section and the questionnaire itself. An example of the item construction is included.

To what extent do you experience shopping in a way that is so enjoyable that you would do it again just for the sake of it?

\begin{tabular}{l|l|l|l|l|l|l|l|}
\hline Not at all & 1 & 2 & 3 & 4 & 5 & 6 & 7 \\
\hline
\end{tabular}

How often do you feel a sense of happiness whilst out shopping?

Hardly ever

\begin{tabular}{|l|l|l|l|l|l|l|}
\hline 1 & 2 & 3 & 4 & 5 & 6 & 7 \\
\hline
\end{tabular}

Procedure

A total of 426 copies of the SES were handed out to the undergraduate university students. The respondents completed the survey in a single session. Four hundred and twenty six completed questionnaires were returned yielding a response rate of $100 \%$. Although the response rate was $100 \%$ there were nine questionnaires that had incomplete biographical information. The questionnaires with incomplete biographical information were excluded from further statistical analysis. All the surveys were completed in English. The survey was administered in cooperation with the Department of Industrial Psychology.

\section{RESULTS}

Shopping Experience Survey (SES)

The first statistical analysis performed was to ascertain whether the SES had a sound enough structure for further statistical analyses to be conducted. Table 2 gives the results of the KaiserMeyer-Olkin Measure of Sampling Adequacy (MSA) applied to the questionnaire. An MSA of 0,965 was obtained. On the basis of the obtained MSA value, the 54 items of the SES were intercorrelated and subjected to factor analysis. The eigenvalues of the unreduced intercorrelation matrix $(54 \times 54)$ are given in Table 3. From an inspection of Table 3 it is clear that nine eigenvalues are greater than unity, indicating nine factors. Table 4 gives the rotated factor matrix (Varimax rotation). As the intercorrelation matrix of items is of order $54 \times 54$, it is too large to be reproduced in this paper, but would be made available on request. Nine factors were extracted, but four factors were poorly determined, therefore four of the factors were discarded. Subscores were calculated for each of the remaining factors. The subscores were intercorrelated and the results are given in Table 5. The intercorrelation matrix was subjected to a principal factor analysis and yielded a single factor, which is given in Table 6 .

TABLE 2

THE KAISER-MEYER-OLKIN MEASURE OF SAMPLING ADEQUACY (MSA) IN RESPECT OF THE SES

\begin{tabular}{lrr}
\hline Kaiser-Meyer-Olkin Measure Of Sampling Adequacy & 0,965 \\
Bartlett's Test of Sphericity & (Approximate Chi-Square) & 13661 \\
& DF & 1434 \\
& Significance & $<0,001$ \\
\hline
\end{tabular}

TABLE 3

EIGENVALUES OF UNREDUCED INTERCORRELATION MATRIX

\begin{tabular}{|c|c|c|}
\hline Root & Eigenvalue & Cumulative $\%$ of variance \\
\hline 1 & 21,129 & 39,127 \\
\hline 2 & 3,050 & 44,776 \\
\hline 3 & 2,478 & 49,364 \\
\hline 4 & 1,705 & 52,522 \\
\hline 5 & 1,225 & 54,790 \\
\hline 6 & 1,208 & 57,028 \\
\hline 7 & 1,125 & 59,111 \\
\hline 8 & 1,089 & 61,128 \\
\hline 9 & 1,004 & 62,988 \\
\hline 10 & 0,936 & 64,720 \\
\hline 11 & 0,923 & 66,430 \\
\hline 12 & 0,845 & 67,995 \\
\hline 13 & 0,834 & 69,539 \\
\hline 14 & 0,785 & 70,993 \\
\hline 15 & 0,753 & 72,388 \\
\hline 16 & 0,735 & 73,748 \\
\hline 17 & 0,707 & 75,057 \\
\hline 18 & 0,651 & 76,263 \\
\hline 19 & 0,625 & 77,420 \\
\hline 20 & 0,617 & 78,562 \\
\hline 21 & 0,577 & 79,630 \\
\hline 22 & 0,574 & 80,693 \\
\hline 23 & 0,533 & 81,679 \\
\hline 24 & 0,523 & 82,648 \\
\hline 25 & 0,509 & 83,592 \\
\hline 26 & 0,484 & 84,488 \\
\hline 27 & 0,471 & 85,360 \\
\hline 28 & 0,439 & 86,174 \\
\hline 29 & 0,428 & 86,966 \\
\hline 30 & 0,423 & 87,749 \\
\hline 31 & 0,394 & 88,478 \\
\hline 32 & 0,388 & 89,197 \\
\hline 33 & 0,377 & 89,895 \\
\hline 34 & 0,373 & 90,585 \\
\hline 35 & 0,353 & 91,240 \\
\hline 36 & 0,344 & 91,877 \\
\hline 37 & 0,337 & 92,500 \\
\hline 38 & 0,307 & 93,068 \\
\hline 39 & 0,305 & 93,633 \\
\hline 40 & 0,297 & 94,183 \\
\hline 41 & 0,292 & 94,723 \\
\hline 42 & 0,279 & 95,240 \\
\hline 43 & 0,271 & 95,743 \\
\hline 44 & 0,268 & 96,238 \\
\hline 45 & 0,249 & 96,699 \\
\hline 46 & 0,239 & 97,141 \\
\hline 47 & 0,229 & 97,566 \\
\hline 48 & 0,226 & 97,984 \\
\hline 49 & 0,218 & 98,387 \\
\hline 50 & 0,202 & 98,761 \\
\hline 51 & 0,183 & 99,099 \\
\hline 52 & 0,176 & 99,425 \\
\hline 53 & 0,161 & 99,722 \\
\hline 54 & 0,150 & 100,00 \\
\hline TRACE & 54 & $100 \%$ \\
\hline
\end{tabular}


TABLE 4

ROTATED FACTOR MATRIX OF THE SHOPPING EXPERIENCE SURVEY (VARIMAX)

\begin{tabular}{|c|c|c|c|c|c|c|c|c|c|c|}
\hline & & & & & Factor & & & & & \\
\hline & 1 & 2 & 3 & 4 & 5 & 6 & 7 & 8 & 9 & $\mathbf{h}^{2} \mathbf{j}$ \\
\hline QB7 & 0,721 & 0,277 & 0,232 & & & & & & & 0,706 \\
\hline QB30 & 0,717 & 0,235 & 0,247 & & & & & & & 0,710 \\
\hline QB8 & 0,705 & 0,280 & 0,214 & & & & & & & $0,68 c$ \\
\hline QB19 & 0,705 & 0,258 & & $-0,235$ & & & & & & 0,733 \\
\hline QB49 & 0,701 & 0,249 & 0,260 & & & & & & & 0,668 \\
\hline QB32 & 0,668 & 0,348 & 0,254 & & & & & & & 0,692 \\
\hline QB10 & 0,667 & 0,366 & & & & & 0,201 & & & 0,688 \\
\hline QB37 & 0,633 & 0,382 & 0,251 & $-0,232$ & & & 0,209 & & & 0,716 \\
\hline QB50 & 0,632 & 0,255 & & & & & & & & 0,552 \\
\hline QB43 & 0,626 & 0,390 & 0,321 & $-0,201$ & & & & & & 0,734 \\
\hline QB11 & 0,615 & 0,285 & 0,230 & & & $-0,253$ & & & & 0,593 \\
\hline QB20 & 0,590 & 0,361 & 0,210 & $-0,243$ & & & 0,231 & & & 0,637 \\
\hline QB6 & 0,582 & 0,340 & 0,251 & & & & & & 0,226 & 0,631 \\
\hline QB53 & 0,544 & & 0,297 & & 0,254 & & & & & 0,520 \\
\hline QB39 & 0,536 & 0,353 & 0,397 & $-0,368$ & & & & & & 0,723 \\
\hline QB23 & 0,530 & 0,257 & & & 0,227 & & & & & 0,462 \\
\hline QB52 & 0,520 & 0,328 & 0,405 & $-0,303$ & & & & & & 0,647 \\
\hline QB24 & 0,501 & 0,343 & & & & & & & & 0,44 \\
\hline QB5 & 0,490 & 0,466 & 0,202 & & & & & $-0,233$ & & 0,597 \\
\hline QB51 & 0,487 & 0,464 & 0,206 & & & & & & & 0,579 \\
\hline QB14 & 0,465 & & & & & & & 0,400 & & 0,503 \\
\hline QB44 & 0,452 & 0,293 & 0,347 & & & & & & & 0,483 \\
\hline QB12 & 0,447 & 0,299 & 0,416 & & & & & 0,209 & 0,314 & 0,647 \\
\hline QB13 & 0,397 & & 0,292 & & & & & 0,331 & & 0,397 \\
\hline QB48 & $-0,396$ & & & 0,376 & & 0,295 & $-0,264$ & & & 0,490 \\
\hline QB25 & 0,379 & 0,244 & & & & & & & & 0,268 \\
\hline QB28 & 0,367 & 0,227 & & & & & 0,363 & & & 0,357 \\
\hline QB2 & & 0,727 & & & & & & & & 0,608 \\
\hline QB16 & 0,279 & 0,719 & & & & & 0,253 & & & 0,708 \\
\hline QB4 & 0,250 & 0,693 & & & & & & $-0,244$ & & 0,665 \\
\hline QB1 & 0,271 & 0,663 & 0,218 & & & & & 0,211 & & 0,617 \\
\hline QB22 & 0,268 & 0,655 & & & & & & & & 0,54 \\
\hline QB36 & 0,389 & 0,637 & & & & & & & & 0,64 \\
\hline QB17 & 0,434 & 0,534 & & $-0,203$ & & & & & & 0,594 \\
\hline QB18 & 0,428 & 0,530 & & & & & & & & 0,553 \\
\hline QB29 & 0,289 & 0,348 & & & & & & & & 0,28 \\
\hline QB9 & 0,300 & 0,343 & 0,221 & & & 0,210 & 0,223 & & & 0,379 \\
\hline QB42 & 0,255 & 0,204 & 0,695 & $-0,206$ & & & & & & 0,64 \\
\hline QB40 & 0,313 & 0,236 & 0,607 & & & & & & & 0,60 \\
\hline QB3 & 0,299 & 0,210 & 0,554 & & & & & & 0,307 & 0,588 \\
\hline QB33 & 0,474 & & 0,500 & $-0,226$ & & & & & & 0,601 \\
\hline QB31 & 0,256 & 0,234 & 0,483 & & & & 0,284 & & & 0,507 \\
\hline QB45 & 0,294 & 0,229 & 0,454 & & & & & & & 0,421 \\
\hline QB54 & 0,202 & & 0,369 & & & & & & & 0,258 \\
\hline QB34 & $-0,244$ & & $-0,258$ & 0,747 & & & & & & 0,717 \\
\hline QB47 & $-0,226$ & & & 0,654 & & & & & & 0,527 \\
\hline QB35 & $-0,259$ & & $-0,246$ & 0,488 & 0,349 & & & & $-0,263$ & 0,567 \\
\hline QB15 & $-0,361$ & & & 0,373 & & 0,270 & & $-0,271$ & & 0,42 \\
\hline QB26 & 0,210 & & & & 0,609 & & & & & 0,512 \\
\hline QB41 & & & & & 0,589 & & & & & 0,398 \\
\hline QB38 & & & & 0,339 & 0,521 & & & & $-0,206$ & 0,487 \\
\hline QB46 & & & & & & 0,633 & & & & 0,465 \\
\hline QB21 & & & & & & 0,513 & & & & 0,339 \\
\hline QB27 & 0,248 & & & & & & 0,331 & & & 0,235 \\
\hline
\end{tabular}

TABLE 5

MATRIX OF INTERCORRELATIONS OF THE SUBSCORES IN RESPECT OF THE SES

\begin{tabular}{lccccc}
\hline & Subscore 1 & Subscore 2 & Subscore 3 & Subscore 4 & Subscore 5 \\
\hline Subscore 1 & 1,000 & & & & \\
Subscore 2 & 0,820 & 1,000 & & & \\
Subscore 3 & $-0,241$ & $-0,233$ & 1,000 & & \\
Subscore 4 & 0,316 & 0,252 & $-0,121$ & 1,000 & \\
Subscore 5 & $-0,497$ & $-0,546$ & 0,444 & $-0,002$ & 1,000 \\
\hline
\end{tabular}

TABLE 6

SINGLE FACTOR SOLUTION IN RESPECT OF THE SES

\begin{tabular}{lll}
\hline & Factor $\mathbf{1}$ & $\mathbf{h}^{\mathbf{2}} \mathbf{j}$ \\
\hline Factor 1 & 0,984 & 0,968 \\
Factor 2 & 0,760 & 0,578 \\
Factor 3 & 0,807 & 0,651 \\
Factor 4 & 0,556 & 0,309 \\
Factor 5 & 0,397 & 0,157 \\
\hline
\end{tabular}

Using the NP50 programme, an item analysis was performed on the SES. The iterative process identified four items to be removed as their removal increased the overall reliability. The four items identified for removal are items $21,38,41$ and 46 . In addition to these items a further eight items were identified with poorer indices of reliability. However, with the removal of the additional eight items the overall reliability of the SES only increased from 0,969 to 0,970 . Before removing the additional eight items, the overall validity of the SES was considered. Accordingly, an additional four items (26, 27, 28 and 48) were removed. This amended scale yielded an overall reliability of 0,969 according to Cronbach's coefficient alpha. The item statistics of the amended scale are given in Table 7.

In addition to test reliability, it is important that an instrument be able to discriminate between groups in a practical situation. In this respect a secondary objective of the study was to determine whether there are differences between groups in respect of their shopping experiences. Biographical information was obtained in respect of age, gender, race, level of income and frequency of shopping behaviour. As all the respondents fell within the 18-24 age category the possibility of age comparisons were negated. As all the participants were full-time students, there was little opportunity for income comparisons to be made as most of them earned less than $\mathrm{R} 1000$ per month $(\mathrm{N}=277)$. For a meaningful comparison to be made participants falling in the categories (R1001-R2500; R2501-R5000; R5001-R8500 and $\mathrm{R} 8500^{+}$) were grouped together (combined $\mathrm{N}=126$ ) and contrasted with those earning less than R1000 per month. An independent samples t-test for the equality of means on the SES was applied to the two income groups but yielded no statistically significant difference.

The results in respect of the gender comparison with regard to shopping experiences yielded a statistically significant difference. From Table 8 it can be seen that there is a statistically significant difference between the means of men $(3,467)$ and women $(4,029)$ in respect of their experience of shopping $(\mathrm{p}=$ $0,001)$. From their mean scores, it would appear that women derive a greater sense of flow whilst engaging in shopping behaviour compared to men. This may suggest that men view shopping as more functional whilst women view shopping as more experiential. 
TABLE 7

ITEM STATISTICS IN RESPECT OF THE SES

\begin{tabular}{|c|c|c|c|c|}
\hline Item & Mean of item & $\begin{array}{l}\text { SD of item } \\
\text { correlation }\end{array}$ & $\begin{array}{l}\text { Item-total } \\
\text { index }\end{array}$ & Item reliability \\
\hline & $\bar{X}_{g}$ & Sg & $r_{g x}$ & $r_{g x} S_{g}$ \\
\hline 1 & 4,071 & 1,827 & 0,648 & 1,184 \\
\hline 2 & 3,118 & 1,566 & 0,526 & 0,823 \\
\hline 3 & 3,602 & 1,827 & 0,630 & 1,151 \\
\hline 4 & 2,553 & 1,617 & 0,605 & 0,979 \\
\hline 5 & 3,047 & 1,689 & 0,638 & 1,078 \\
\hline 6 & 3,428 & 1,727 & 0,721 & 1,245 \\
\hline 7 & 4,555 & 1,626 & 0,780 & 1,267 \\
\hline 8 & 4,595 & 1,550 & 0,772 & 1,196 \\
\hline 9 & 3,313 & 1,579 & 0,554 & 0,875 \\
\hline 10 & 3,828 & 1,593 & 0,764 & 1,218 \\
\hline 11 & 4,207 & 1,563 & 0,672 & 1,050 \\
\hline 12 & 3,993 & 1,930 & 0,700 & 1,351 \\
\hline 13 & 4,953 & 1,629 & 0,470 & 0,765 \\
\hline 14 & 5,468 & 1,447 & 0,573 & 0,829 \\
\hline 15 & 5,424 & 1,678 & 0,422 & 0,707 \\
\hline 16 & 2,875 & 1,572 & 0,654 & 1,029 \\
\hline 17 & 3,642 & 1,518 & 0,719 & 1,092 \\
\hline 18 & 3,955 & 1,621 & 0,689 & 1,117 \\
\hline 19 & 4,635 & 1,459 & 0,788 & 1,150 \\
\hline 20 & 4,028 & 1,163 & 0,778 & 1,256 \\
\hline 21 & 3,252 & 1,553 & $0,032 *$ & 0,050 \\
\hline 22 & 3,675 & 1,769 & 0,598 & 1,058 \\
\hline 23 & 4,562 & 1,639 & 0,640 & 1,048 \\
\hline 24 & 4,280 & 1,758 & 0,645 & 1,134 \\
\hline 25 & 4,245 & 1,795 & 0,518 & 0,930 \\
\hline 26 & 5,588 & 1,407 & 0,326 & 0,459 \\
\hline 27 & 3,649 & 1,639 & 0,400 & 0,655 \\
\hline 28 & 3,906 & 1,499 & 0,505 & 0,756 \\
\hline 29 & 3,748 & 1,958 & 0,498 & 0,974 \\
\hline 30 & 4,774 & 1,508 & 0,788 & 1,189 \\
\hline 31 & 3,271 & 1,750 & 0,599 & 1,047 \\
\hline 32 & 3,991 & 1,667 & 0,789 & 1,315 \\
\hline 33 & 3,847 & 1,700 & 0,719 & 1,223 \\
\hline 34 & 4,544 & 1,834 & 0,529 & 0,970 \\
\hline 35 & 3,546 & 1,668 & 0,413 & 0,688 \\
\hline 36 & 3,339 & 1,619 & 0,700 & 1,133 \\
\hline 37 & 3,835 & 1,738 & 0,808 & 1,405 \\
\hline 38 & 3,247 & 1,574 & $0,165^{*}$ & 0,259 \\
\hline 39 & 3,805 & 1,729 & 0,794 & 1,373 \\
\hline 40 & 3,560 & 1,691 & 0,629 & 1,064 \\
\hline 41 & 5,268 & 1,429 & $0,199 *$ & 0,284 \\
\hline 42 & 3,687 & 1,680 & 0,632 & 1,062 \\
\hline 43 & 3,887 & 1,586 & 0,810 & 1,284 \\
\hline 44 & 3,562 & 1,766 & 0,670 & 1,184 \\
\hline 45 & 3,536 & 1,760 & 0,473 & 0,833 \\
\hline 46 & 3,365 & 1,593 & $0,122^{*}$ & 0,199 \\
\hline 47 & 4,442 & 1,798 & 0,472 & 0,848 \\
\hline 48 & 4,492 & 1,653 & 0,380 & 0,629 \\
\hline 49 & 3,960 & 1,569 & 0,761 & 1,195 \\
\hline 50 & 4,144 & 1,525 & 0,682 & 1,040 \\
\hline 51 & 3,355 & 1,830 & 0,709 & 1,296 \\
\hline 52 & 3,602 & 1,756 & 0,766 & 1,345 \\
\hline 53 & 4,532 & 1,645 & 0,645 & 1,062 \\
\hline 54 & 4,661 & 1,745 & 0,414 & 0,723 \\
\hline
\end{tabular}

Note * Item-total correlations are too low for these items to be included in the scale
TABLE 8

T-TEST: COMPARISON OF THE MEANS OF GENDER GROUPS IN RESPECT OF THE SES

\begin{tabular}{|c|c|c|c|c|c|c|c|c|}
\hline Gender & $\mathbf{N}$ & Mean & SD & F & $\mathrm{p}(\mathrm{F})$ & $t$ & df & $p(t)$ \\
\hline \multirow[t]{2}{*}{ Male } & 116 & 3,4668 & 0,9309 & 0,619 & 0,432 & $-5,562$ & 417 & $<0,001$ \\
\hline & & & 1 & & & & & * \\
\hline \multirow[t]{2}{*}{ Female } & 303 & 4,0285 & 0,9227 & & & & & \\
\hline & & & 8 & & & & & \\
\hline
\end{tabular}

*Statistically significant

TABLE 9

ANOVA: COMPARISON OF THE MEANS OF THE RACE GROUPS IN RESPECT OF THE SES

\begin{tabular}{lccccc}
\hline Source of variation & $\begin{array}{c}\text { Sum of } \\
\text { squares }\end{array}$ & Df & Mean square & F & p(F) \\
\hline Between groups & 11,084 & 3 & 3,695 & 4,100 & $0,007^{*}$ \\
Within groups & 373,068 & 414 & 0,901 & & \\
Total & 384,152 & 417 & & & \\
\hline
\end{tabular}

* Statistically significant

In order to determine whether statistically significant differences exist between race groups a one-way ANOVA was conducted. Levene's test for equality of variances indicated that there were differences between these groups and consequently a Dunnette T3 post-hoc comparison was applied. The results in Table 10 indicate that there is a statistically significant difference between the means of Black and White respondents $(p=0,016)$. The mean comparison was conducted after transforming the raw scores to a seven-point scale. In this respect, White respondents obtained a mean of $(3,760)$ and Black respondents a mean of $(4,169)$. The difference is small, but nevertheless statistically significant.

In addition to providing biographical information, the respondents were asked to indicate the frequency with which they engaged in shopping. The frequencies ranged from very seldom to more than three times per month. In Table 11 it can be can be seen that $40 \%$ of the respondents $(\mathrm{N}=170)$ engaged in shopping more than three times a month. The four categories (very seldom, twice monthly, three times a month, more than three times a month) were consolidated to form two new categories. The first category combined the responses of the, "very seldom" and, "twice monthly" categories $(\mathrm{N}=183$, representing $43,9 \%$ of total responses). The second category combined the responses of the, "three times a month" and, "more than three times a month" categories $(\mathrm{N}=234$, representing $56,1 \%$ of total responses). Table 12 shows that the two emergent groups were then compared according to their raw score means on the SES (as opposed to mean of means) to determine the magnitude of the effect size. A t-test was performed on the emergent groups and the resultant effect size was $d=0,586$. According to Cohen (1988), an effect size of $d=0,5$ is judged as a medium effect. 
TABLE 10

COMPARISON OF THE MEANS OF THE RACE GROUPS IN RESPECT OF THE SES

\begin{tabular}{|c|c|c|c|c|c|c|c|c|c|c|c|c|c|c|}
\hline \multirow[b]{2}{*}{ Variable } & \multicolumn{4}{|c|}{ Means } & \multicolumn{4}{|c|}{ Standard Deviations } & \multicolumn{6}{|c|}{ Groups } \\
\hline & A & B & $\mathrm{C}$ & $\mathrm{D}$ & A & B & $\mathrm{C}$ & D & A/B & $\mathrm{A} / \mathrm{C}$ & $\mathrm{A} / \mathrm{D}$ & $\mathrm{B} / \mathrm{C}$ & B/D & C/D \\
\hline \multirow[t]{2}{*}{ SES score } & 3,9495 & 4,1686 & 4,115 & 3,759 & 0,9911 & 0,9676 & 0,9546 & 0,9369 & 0,80 & 0,97 & 0,76 & 1,00 & $0,016^{*}$ & 0,35 \\
\hline & & 6 & 1 & 9 & 9 & 1 & 5 & 5 & 3 & 8 & 2 & 0 & & 5 \\
\hline
\end{tabular}

* Statistically significant

Note:

A $=$ Asian

$\mathrm{B}=$ Black

$\mathrm{C}=$ Coloured

$\mathrm{D}=$ White

TABLE 11

FREQUENCY DISTRIBUTION IN RESPECT OF SHOPPING BEHAVIOUR

\begin{tabular}{lcc}
\hline & On average, how often do you go shopping? \\
\hline & $\mathrm{N}$ & $\%$ \\
Very seldom & 82 & 19,3 \\
Twice monthly & 103 & 24,2 \\
Three times a month & 70 & 16,5 \\
More than three times a month & 170 & 40,0 \\
\hline
\end{tabular}

\section{DISCUSSION}

In contrast to traditional approaches to understanding consumer behaviour, this paper holds that shopping is not simply a means to an end but in many cases an end in itself, actively pursued by individuals. The primary purpose of this study was the construction and evaluation of a scale to elicit support for the supposition that individuals engage in shopping because they derive something pleasant from the experience other than the physical product. Whilst the SES indicates that individuals actively engage in shopping to derive something from the experience other than a product or brand, the instrument does not determine what that experience is or suggest what it should be. The experience of the consumer may be simple in some cases as with play, leisure, affiliation or fun and more complex in other instances with respect to aesthetic appreciation or the experience of flow.

A secondary objective of the study was to establish whether or not there were statistically significant differences in respect of the SES. These differences were compared across gender, income, age and race.

With respect to age and income no statistically significant results were obtained. There was, however, support for the first hypothesis, namely that statistically significant differences exist in respect of the shopping experiences of different race groups (Asian, Black, Coloured, White). The results confirm a statistically significant difference between Blacks and Whites. In addition to this, the second hypothesis is supported with males and females displaying a statistically significant difference in their reported experience of shopping.

Although the SES yielded a high reliability and was able to discriminate between groups, the limitation of the instrument is that it doesn't highlight where or why those differences exist, it just confirms that they do. An additional limitation of this study is that the survey does not indicate what motivates individuals to engage in shopping. Because the Shopping Experience Survey does not explain why the individual is behaving in a certain way, it reduces the predictive power thereof and hence lowers the practical value of the instrument.

An important implication of this study is to create awareness, particularly within marketing disciplines - that to ignore the experience of the consumer is perilous. The environment in which the consumer may interact with a product or brand may in some cases be the reason consumption happens. The study also has important implications for the design of web based on-line shopping environments where it is not the power of the brand that will keep consumers interested but rather the navigability, on-line environment and experience of the site that may make the ultimate difference in attracting customers, building brand equity and sustaining brand loyalty (Hoffman \& Novak, 1996).

On the basis of this study a number of research possibilities present themselves for further investigation. The actual measures of the identified outcomes of this paper and their link to the shopping experience should be expanded upon. In other words, what is the relationship between leisure and shopping? Under what circumstances would they be present and how would this affect consumer behaviour? In addition to this aspect it would be important to understand exactly where the differences in the shopping experience lie between men and women. Similarly, a deeper understanding of the differences between the shopping experiences of race groups would present important empirical data.

TABLE 12

COMPARISON OF THE MEANS OF OCCASIONAL SHOPPERS AND FREQUENT SHOPPERS IN RESPECT OF THE SES

\begin{tabular}{|c|c|c|c|c|c|c|c|c|c|c|c|c|c|}
\hline & & Group 1 & & & Group 2 & & & & & & & & \\
\hline VARIABLE & & & & & & & F & df & $\mathrm{p}(\mathrm{F})$ & $\mathrm{t}$ & df & $p(t)$ & d \\
\hline \multirow{2}{*}{$\begin{array}{l}\text { Shopping } \\
\text { experience }\end{array}$} & 163,9 & 42,68 & 183 & 188,7 & 41,92 & 234 & 1,11 & 1,41 & 0,29 & - & 415 & $<0,001$ & 0,58 \\
\hline & 8 & 4 & & 1 & 9 & & 5 & 5 & 2 & 5,929 & & & 6 \\
\hline
\end{tabular}

Note: Cohen's effect size $d=0,586$. This is a medium effect. 


\section{REFERENCES}

Abbott, L. (1955). Quality and competition. New York: Columbia University Press

Apter, M.J. (1982). The experience of motivation: The theory of psychological reversals. London: Academic Press

Bellenger, D.N. \& Korgaonkar, P. (1980). Profiling the recreational shopper. Journal of Retailing. 56 (3), 77-92.

Bhat, S., \& Reddy, S.K. (1998). Symbolic and functional positioning of brands. Journal of Consumer Marketing. 15 (11), 1-9.

Bond, E.J. (1983). Reason and value. Cambridge: Cambridge University Press.

Cohen, J. (1988). Statistical power analysis for the behavioural sciences ( $2^{\text {nd }}$ ed.). Hillside, NJ: Lawrence Earlbaum.

Csikszentmihalyi, M. (1990). Flow. The psychology of optimal experience. New York: Harper and Row.

East, R. (1997). Consumer behaviour: Advances and applications in marketing. London: Prentice Hall.

Foxall, G., Goldsmith, R, \& Brown, S. (1998). Consumer psychology for marketing. London: Thompson Business Press.

Hampshire, S. (1982). Thought and action. Notre Dame: University of Notre Dame Press

Hoffman, D.L \& Novak, T.P. (1996). Marketing in hypermedia computer-mediated environments: Conceptual foundations. Journal of Marketing, 60 (6), 50-68.

Holbrook, M.B., \& Hirschman, E.C (1982). The experiential aspects of consumption: Consumer fantasies, feelings, and fun. Journal of Consumer Research, 9 (3), 132-140.
Holbrook, M.B. (1999). Consumer value: A framework for analysis and research. New York: Routledge

Huber, F., Herrman, A., \& Morgan, R.E. (2001). Gaining competitive advantage through customer value oriented management. Journal of Consumer Marketing. 18 (1), 41-53.

Kelly, J.R. (1987). Freedom to be: A new sociology of leisure. New York: Macmillan

Krubski, J. (1997). It's not simply "change", it's "evolution". Journal of Consumer Marketing. 14 (5), 334-337.

Neulinger, J. (1974). The psychology of leisure. Springfield, Illinois: Charles C. Thomas.

Ohanian, R. \& Taschian, A. (1992). Consumers' shopping effort and evaluation of store image attributes: The roles of purchasing involvement and recreational shopping interest. Journal of Applied Business Research, 8 (4), 40-49.

Overton, N. (1981). Die rol van verbruikersorientasie in die gekommunikeerde effekte van advertensies. Unpublished doctoral script. Rand Afrikaans University.

Park, C.W., Jaworski, B.J., \& MacInnis, D.J. (1986). Strategic brand concept image management. Journal of Marketing, 50 (10), 135-145.

Schiffman, L.G. \& Kanuk, L.L. (1994). Consumer behavior. New Jersey: Prentice-Hall.

Stell, R. \& Paden, N. (1999). Vicarious exploration and catalogue shopping. Journal of Consumer Marketing, 16 (4), 332-346.

Woodruff, R.B \& Gardial, S. (1996). Know your customer: New approaches to understanding customer value and satisfaction. Oxford: Oxford University press. 